\title{
"Poetic naturalism" as a way beyond the postmodern tensions between art and science
}

\author{
Jared Vaughan Davis \\ SciArt Center, New York, NY, USA \\ Correspondence to: Jared Vaughan Davis. SciArt Center, New York, NY, USA. Email: jvdavis.beijing@gmail.com.
}

Submitted Feb 24, 2018. Accepted for publication Mar 05, 2018.

doi: $10.21037 /$ cdt.2018.03.04

View this article at: http://dx.doi.org/10.21037/cdt.2018.03.04

Utilizing a dialectical approach in both my studio practice and research, my aim is to move beyond the contemporary paradigm of postmodern anti-rationalism towards an artistic discourse that oscillates between a "modern enthusiasm" and a "postmodern irony". The concept that factors most heavily in my work is that of "poetic (or romantic) naturalism"-a postpostmodern worldview that venerates our natural reality (as understood by science to be composed entirely of mindless, meaningless particles) in both its objective (scientific) and subjective (poetic) manifestations. Conjuring this temper, in Figures 1-5, I've moved back and forth between digital and traditional mediums, attempting to steadily waver between unity and multiplicity, totality and fragmentation, and reason and romanticism. As in this series (Figures 1-5), the themes of my work range from astronomy, cosmology, physics, and neuroscience, to epistemology, mythology, metaphysics, science fiction, and the science of "belief".

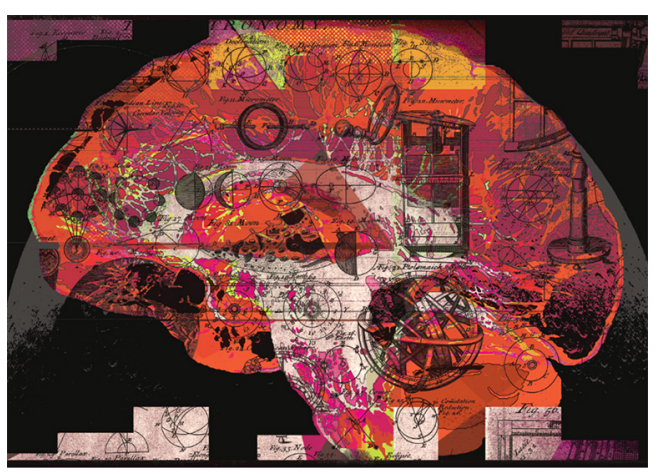

Figure 1 Moon illusion, 2017. Mixed media, $50 \mathrm{~cm} \times 50 \mathrm{~cm}$.

\begin{abstract}
About the artist
Jared Vaughan Davis is a New York-based artist and designer who explores the tensions between art and science through abstractions and multimedia collages that are influenced by philosophical and scientific concepts. He holds a Master's degree in Art and Science from Central Saint Martins (London), and has exhibited work in the United States, United Kingdom, and China. He is affiliated with The SciArt Center. For more information about Davis and his work, visit www.jaredvaughandavis.com.
\end{abstract}

\section{Acknowledgements}

None.

\section{Footnote}

Conflicts of Interest: The author has no conflicts of interest to declare.

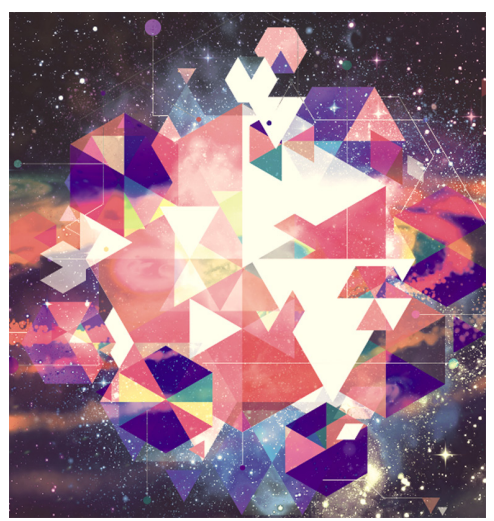

Figure 2 Ionian enchantment, 2017. Mixed media, $85 \mathrm{~cm} \times 60 \mathrm{~cm}$. 


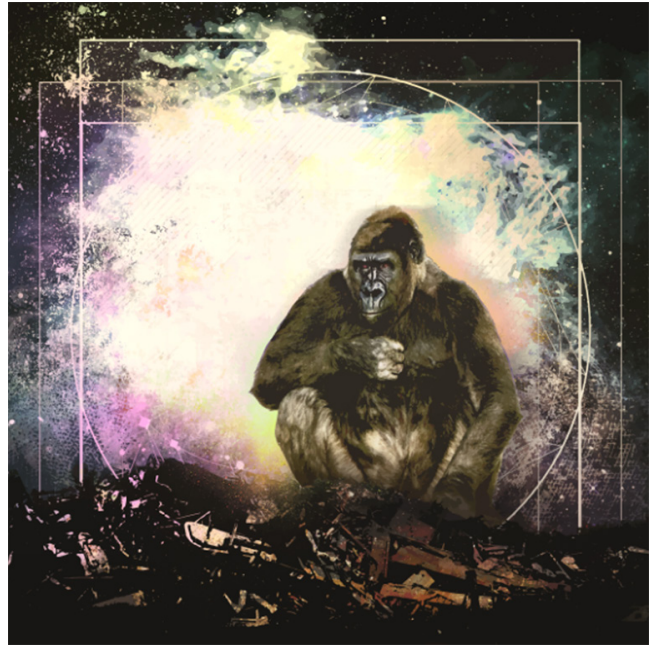

Figure 3 Contemplating the void, 2017. Mixed media, $40 \mathrm{~cm} \times 40 \mathrm{~cm}$.
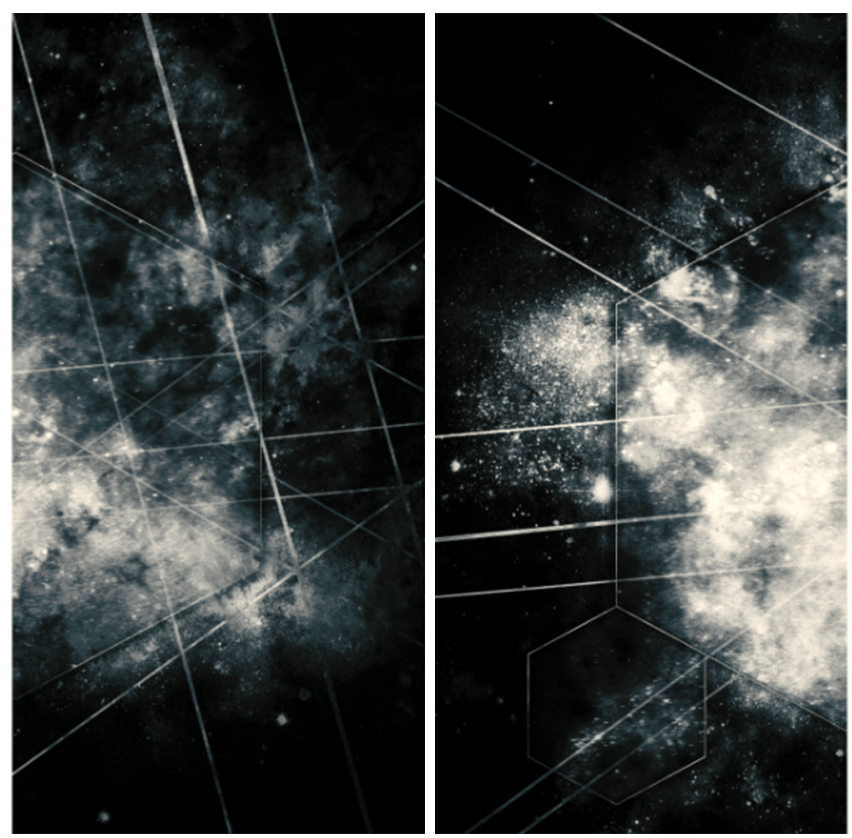

Figure 5 Absolute recoil, 2015. Mixed media, $40 \mathrm{~cm} \times 40 \mathrm{~cm}$.

Cite this article as: Davis JV. "Poetic naturalism" as a way beyond the postmodern tensions between art and science. Cardiovasc Diagn Ther 2018;8(6):825-826. doi: 10.21037/ cdt.2018.03.04

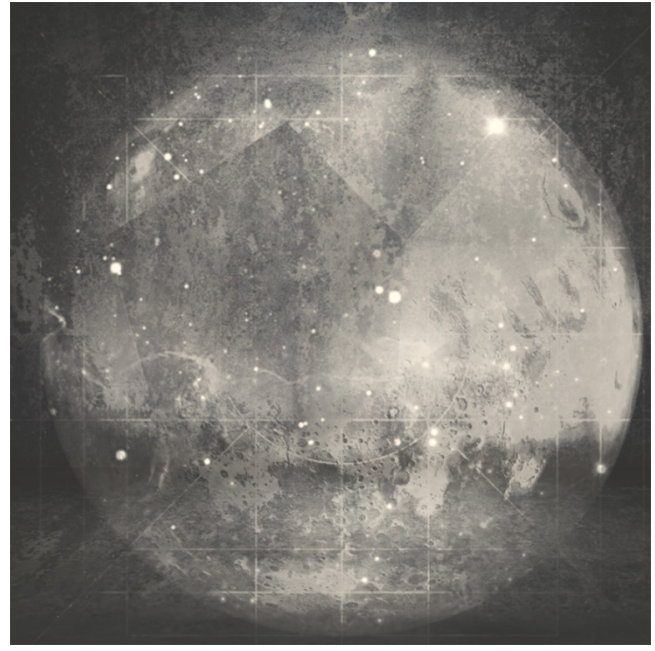

Figure 4 Ontological incompleteness, 2017. Mixed media, $250 \mathrm{~cm} \times 250 \mathrm{~cm}$. 